\title{
Path Analysis of Green Maize Components from Hybrids Cultivated Under Reduced Spacing
}

\author{
Luan de Oliveira Nascimento ${ }^{1}$, Josimar Batista Ferreira ${ }^{1}$, Gleisson de Oliveira Nascimento ${ }^{2}$, \\ Marcio de Oliveira Martins ${ }^{1}$, Antonia Fabiana Barros de Lima ${ }^{1}$, Francisco Ian de Oliveira Nascimento ${ }^{2}$ \\ \& Vanderley Borges dos Santos ${ }^{1}$ \\ ${ }^{1}$ Center for Biological and Natural Sciences, Federal University of Acre, Rio Branco, Acre, Brazil \\ ${ }^{2}$ Multidisciplinary Center, Federal University of Acre, Cruzeiro do Sul, Acre, Brazil \\ Correspondence: Luan de Oliveira Nascimento, Center for Biological and Natural Sciences, Federal University of \\ Acre, Rio Branco, Acre, Brazil. Tel: 55-(68)-99939-5683. E-mail: luan17czs@yahoo.com.br
}

Received: August 25, 2019

Accepted: September 26, 2019

Online Published: November 15, 2019

doi:10.5539/jas.v11n18p131

URL: https://doi.org/10.5539/jas.v11n18p131

\begin{abstract}
The yield and cause and effect relationships of green-ear production components of hybrids cultivated in reduced spaced environments were investigated aiming to increase the green ear harvest, as well as to identify the main characteristics that contribute most to the productivity. Four row spacings were evaluated using three commercial hybrids. The experiment lasted three months and were evaluated: plant height $(\mathrm{PH})$ and ear insertion height $(\mathrm{EIH})$, leaf area (LA), stem diameter (SD), total number of ears, total ear yield, number of ear with straw and without straw, yield of ears with straw (YES) and yield ear without straw (YEWS), ear length (EL) and ear diameter (ED). In addition, the full correlation in direct and indirect effects was performed by the path analysis of the PH, EIH, LA, SD, EL, ED characters on the YEWS. It was found that the reduction of spacing to $60 \mathrm{~cm}$ favors higher YEWS without compromising the quality, size and diameter of the green ears. However, the EL, $\mathrm{EIH}$ and SD are the main characters that directly and indirectly influence the yield of green ears of maize hybrids cultivated in reduced spaced environment.
\end{abstract}

Keywords: correlations, cropping systems, production, Zea mays

\section{Introduction}

Maize (Zea mays L.) is originally from Central America and has acclimatization capacity to various climates, which gives it considerable plasticity and allows its cultivation in many areas of the world (Silveira, Bonetti, Tragnago, Neto, and Monteiro 2015). Corn is grown practically all year round, where it is explored on most farms, cultivated with low technology and subsistence characteristics in addition to technology cultivation and high productivity (Luz, Camilo, Barbieri, Rangel, \& Oliveira, 2014).

Grain production is the main focus in maize cultivation. However, the crop has great consumption versatility, which can also be destined to the production of green maize or silage (Ribeiro, Damaso, Costa, Pelá, \& Rodrigues, 2016). For consumption in natura the green ears are harvested fresh at the physiological stage R3, with water content in the grain ranging from $70 \%$ to $80 \%$ of moisture, presenting characteristics such as color, flavor, texture, length and diameter of the ear suitable for the marketing of ears (Santos et al., 2015). In this context, the green maize crop becomes attractive to small and medium producers, due to the possibilities of added value to the product by the market and also by its demand (Williams, 2014).

In general, few cultivars for green maize are available and recommended for different producing regions. Thus, producers choose to use hybrid maize seeds intended for other markets for the production of green maize (Rodrigues et al., 2018). As an alternative to this market, hybrid maize for grain production may be interesting options for growing green maize (Costa, Damaso, Mendes, Marques, \& Rodrigues, 2015), which combined with reduced row spacing can increase production in small areas (Nascimento, Ferreira, Martins, Nascimento, \& Lima, 2019), without compromising the quality of marketable ears.

Studies on the behavior of cultivars for in natura consumption and cause-and-effect relationship between green ear production components are of great importance to growers (Entringer, Santos, Vettorazzi, Cunha, \& Pereira, 
2014). The information generated by the path analysis contributes to decision of the cultivar to be used and which characteristics influence the main variable (Rocha et al., 2019).

Green ear yield is influenced by several components, so the identification of ear yield characters that make the greatest contribution to yield can assist in selecting cultivars for the green maize market (Entringer et al., 2014). Given this, the knowledge of the correlations through the path analysis allows to outline alternative strategies to maximize the predicted gain with the selection of components directly or indirectly correlated with a main variable (Zuffo, Ribeiro, Bruzi, Zambiazzi, \& Fonseca, 2018).

Therefore, this work was proposed with the objective of verifying the green ear yield potential and direct and indirect relations between the green ear yield components, by means of the path analysis, identifying which trait presents the greatest contribution to the yield of green ears of maize hybrids cultivated in an environment with reduced spacing.

\section{Material and Method}

\subsection{The Area Description}

The experiment was conducted at the 2016/2017 crop at Fazenda São João, located in Senador Guiomard, BR $317-\mathrm{km} 57$, State of Acre, Brazil ( $09^{\circ} 50.9^{\prime} \mathrm{S}$ and $67^{\circ} 26.4^{\prime} \mathrm{W}$ in datum WGS84). The chemical analysis of the soil in the $0-20 \mathrm{~cm}$ layer presented $\mathrm{pH}=5.4 ; \mathrm{P}=10.4 \mathrm{mg} \mathrm{dm}^{-3} ; \mathrm{K}=45.3 \mathrm{mg} \mathrm{dm}^{-3} ; \mathrm{MO}=20.6 \mathrm{~g} \mathrm{dm}^{-3} ; \mathrm{Al}=0.25$ $\mathrm{cmol}_{\mathrm{c}} \mathrm{dm}^{-3} ; \mathrm{Ca}=6.5 \mathrm{cmol}_{\mathrm{c}} \mathrm{dm}^{-3}$ and $\mathrm{Mg}=2.5 \mathrm{cmol}_{\mathrm{c}} \mathrm{dm}^{-3}$.

The monthly data referring to experimental area climatic conditions can be observed in Table 1 .

Table 1. Monthly climatic information in the crop 2016/2017

\begin{tabular}{llll}
\hline Season & Average Temperature $\left({ }^{\circ} \mathrm{C}\right)$ & Relative Humidity $(\%)$ & Precipitation $(\mathrm{mm})$ \\
\hline Novembro (2016) & 26.35 & 84.61 & 169.90 \\
Dezembro (2016) & 26.10 & 87.78 & 219.30 \\
Janeiro (2017) & 25.53 & 94.47 & 405.20 \\
Fevereiro (2017) & 25.72 & 94.04 & 236.50 \\
\hline
\end{tabular}

Source: INMET (2017).

\subsection{Experimental Design and Conduction}

The experimental design used was randomized blocks with split plots with four replications. The treatments resulted from the combinations of corn hybrids in management systems with different spacings. The hybrids were allocated in the plots, and in the subplots were inserted in the row spacing.

In the week before sowing, the weeds present in the area were desiccated with glyphosate (glycine derived systemic herbicide), at the dose of $1,920 \mathrm{~g} \mathrm{ha}^{-1}$ of the active ingrediente, maintaining the dry mass of the desiccated plants as cover.

In minimum tillage system, sowing was done manually in November 2016, in furrows spaced with the distance according to the desired spacing, but the separation between the plants in the planting lines was $20 \mathrm{~cm}$ in all treatments, one seed per pit being used.

The hybrids used were 2B 655 PW (H1), AG 7088 PRO3 (H2) and P4285 YHR (H3). The spacings adopted were $40,60,80$ and $95 \mathrm{~cm}$ row spacing, totaling a final population of 125,$000 ; 83,333 ; 62,500$ and 52,632 plants $\mathrm{ha}^{-1}$, respectively.

The plot area was $96 \mathrm{~m}^{2}$ divided into four subplots of $24 \mathrm{~m}^{2}$, where hybrids were implanted in different line spacing. The line numbers within the subplots varied according to the spacing used. In all subplots, only the central row was considered as a useful area, excluding $50 \mathrm{~cm}$ from the extremity.

The fertilization was performed based on the chemical characteristics of the applied soil $60 \mathrm{~kg} \mathrm{P} \mathrm{ha}^{-1}, 80 \mathrm{~kg} \mathrm{~K}$ $\mathrm{ha}^{-1}$ and $120 \mathrm{~kg} \mathrm{~N} \mathrm{ha}^{-1}$, adjusting the fertilizer distribution for each spacing.

\subsection{Growth Variables}

Moment before harvesting the green ears at the R3 stadium in February 2017, the variables plant height (PH) and ear insertion height $(\mathrm{EIH})$, as well as stem diameter (SD) in $\mathrm{mm}$, were evaluated. These evaluations were performed on ten plants randomly chosen in the useful area of each subplot. 
Additionally, in a plant of the useful area of each subplot, the photosynthetically active leaf area (LA) was calculated by applying Equation 1:

$$
\mathrm{LA}=\Sigma(\mathrm{L} \times \mathrm{S} \times 0.75)
$$

Where, LA: Leaf area $\left(\mathrm{cm}^{2}\right)$; L: Leaf length $(\mathrm{cm})$; S: sheet width $(\mathrm{cm})$.

\subsection{Green Ear Production Variables}

Green ears were harvested manually (90 days after sowing) as the ears reached the milky grain point, stage R3. Thus, all ears of the subplot useful area were harvested and evaluated for the total number of ears per hectare (NE), total ear yield (TEY), number of ears with straw (NES) and without straw (NEWS), yield of ears with straw (YES) and without straw (YEWS), ear length (EL) and ear diameter (ED).

\subsection{Statistical Analysis}

The results were submitted to homogeneity (Bartlett) and error normality analysis (Shapiro-Wilk), and then to variance analysis (ANOVA), and when significant to the means were compared by the Scott-Knott test at 5\% probability. The analyzes were performed using the software ASSISTAT (Silva \& Azevedo, 2016).

Before performing the trail analysis, the phenotypic correlation matrix was obtained and the multicollinearity was verified by the matrix condition number (NC), the ratio between the highest and lowest matrix eigenvalues, proposed by Montgomery and Peck (1981). The presence of severe multicollinearity was observed ( $\mathrm{NC}=$ 1354547.06), and then the path analysis under multicollinearity was performed, applying the constant $\mathrm{k}$ on the main diagonal of the phenotypic correlation matrix.

Thus, the correlations of the characters PH, EIH, SD, LA, EL and ED (explanatory variables) with the YEWS (basic variable) were divided into direct and indirect effects with a chain, establishing the cause and effect relationships between the variables (Cruz \& Carneiro, 2016). All processes for trail analysis were performed with the computer program Genes (Cruz, 2016).

\section{Result and Discussion}

Plant height (Figure 1A), ear insertion height (Figure 1B) and stem diameter (Figure 1D) showed significant differences $(p<0.05)$ between hybrids and spacing, but leaf area (Figure 1C) was not influenced $(p>0.05)$ of the different treatments applied. 

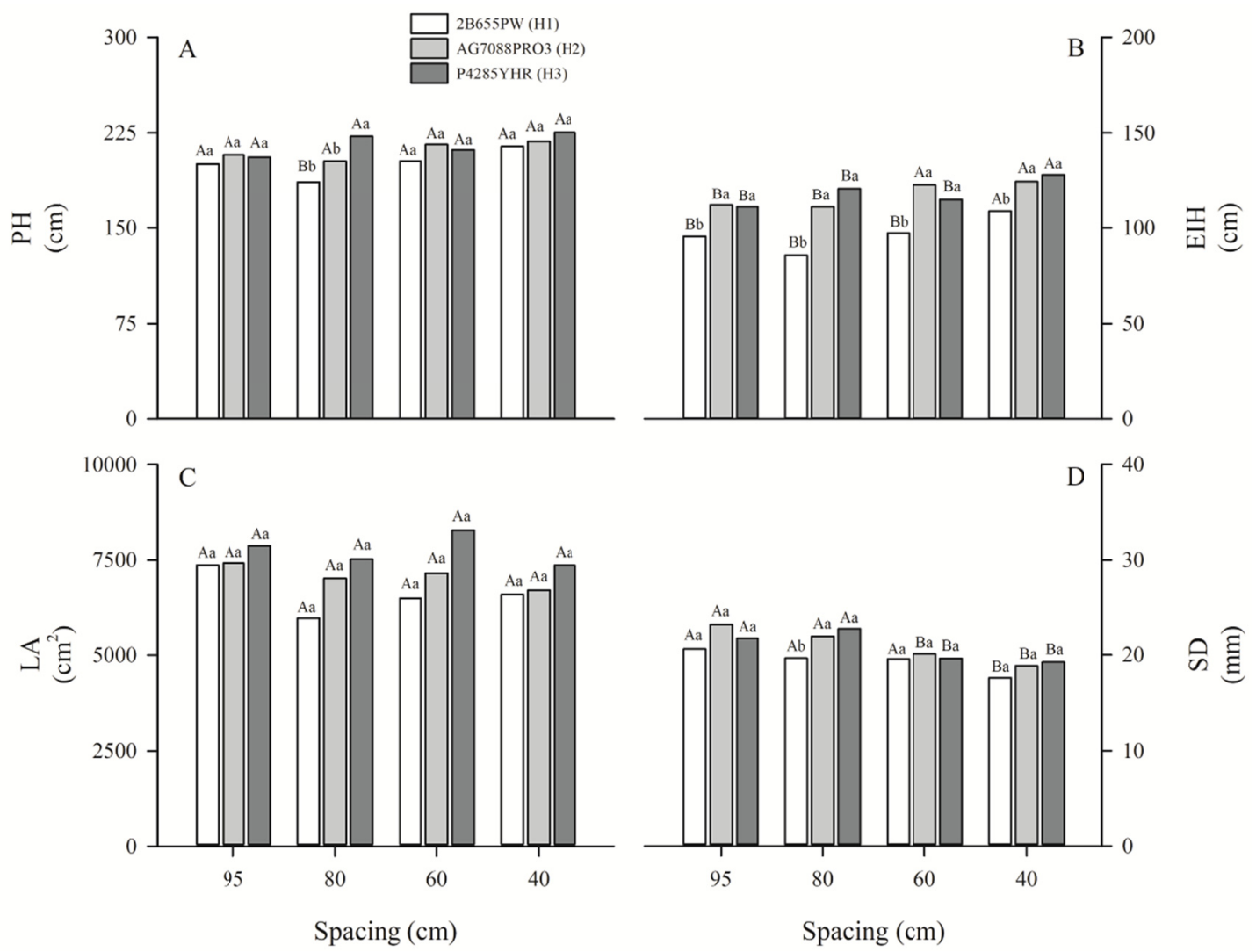

Figure 1. Plant height (A), ear insertion height (B), leaf area (C) and stem diameter (D) of maize hybrids in their respective spacing

Note. Averages followed by the same upper and lower case letters do not show statistical difference $(p>0.05)$ between the spacings and hybrids, respectively, by the Scott-Knott test.

For plant height (AP) hybrids presented average height between $186.25 \mathrm{~cm}$ and $222.25 \mathrm{~cm}$ (Figure 1A), and no differences were observed between spacing for hybrids $\mathrm{H} 1$ and $\mathrm{H} 2$. Notably, there was no significant variation in PA with reduced spacing for H3 hybrid, an interesting result for maize growers, as it suggests cropping systems at higher densities per area, with no risk of plant breakage, commonly evidenced with plants of high postage.

Similar results for PH were observed by Almeida Júnior et al. (2018), according to the authors, the improved plant material and agronomic characteristics established by breeding programs do not suffer large variations in plant height when subjected to higher population densities in the crop, as it is an inherent characteristic of the genotype.

At ear insertion height, it was observed that in the $40 \mathrm{~cm}$ spacing, mainly cultivar H3, presented higher EIH $(128.00 \mathrm{~cm})$ in relation to the other spacings (Figure 1B). This fact can be explained by the intraspecific competition for light that occurs in environments with higher plant densities, which favors stem elongation, which consequently increases ear insertion height without interfering with plant height. However, according to Kuneski et al. (2017), the high number of plants per area increases the competition for light, which provides greater stem growth and consequently the ear will be positioned further away from the soil surface.

For stem diameter (SD) (Figure 1D) it was found that greater distances between rows (95 cm) with higher SD than plants in denser spacing $(40 \mathrm{~cm})$, with $14.56 \%, 18.68 \%$ and $11.60 \%$ of hybrids $\mathrm{H} 1 \mathrm{H} 2$ and $\mathrm{H} 3$, respectively, of superiority. According to Favarato, Souza, and Galvão (2016) the stem diameter acts as an important aspect in crop yield due to its influence on lodging resistance.

With increasing plant population density, changes may occur that increase the percentage of bedridden and broken plants, which consequently reduces the number of ears harvested in the area, contributing to lower green ear yield (Rezende et al., 2015). However, bedridden plants were not found in the experiment suggesting that the hybrids showed resistance to lodging. 
In the components of green ear production it is observed in Figure 2, that there was significant difference ( $p<$ 0.05 ) for hybrids and spacing only in the total number of ears per hectare (Figure 2A). For ear yield per hectare (Figure 2B), number of ears with straw per hectare (Figure 2C) and yield of ears with straw per hectare (Figure $2 \mathrm{D})$ there was a significant difference $(\mathrm{p}<0.05)$ only between spacings.
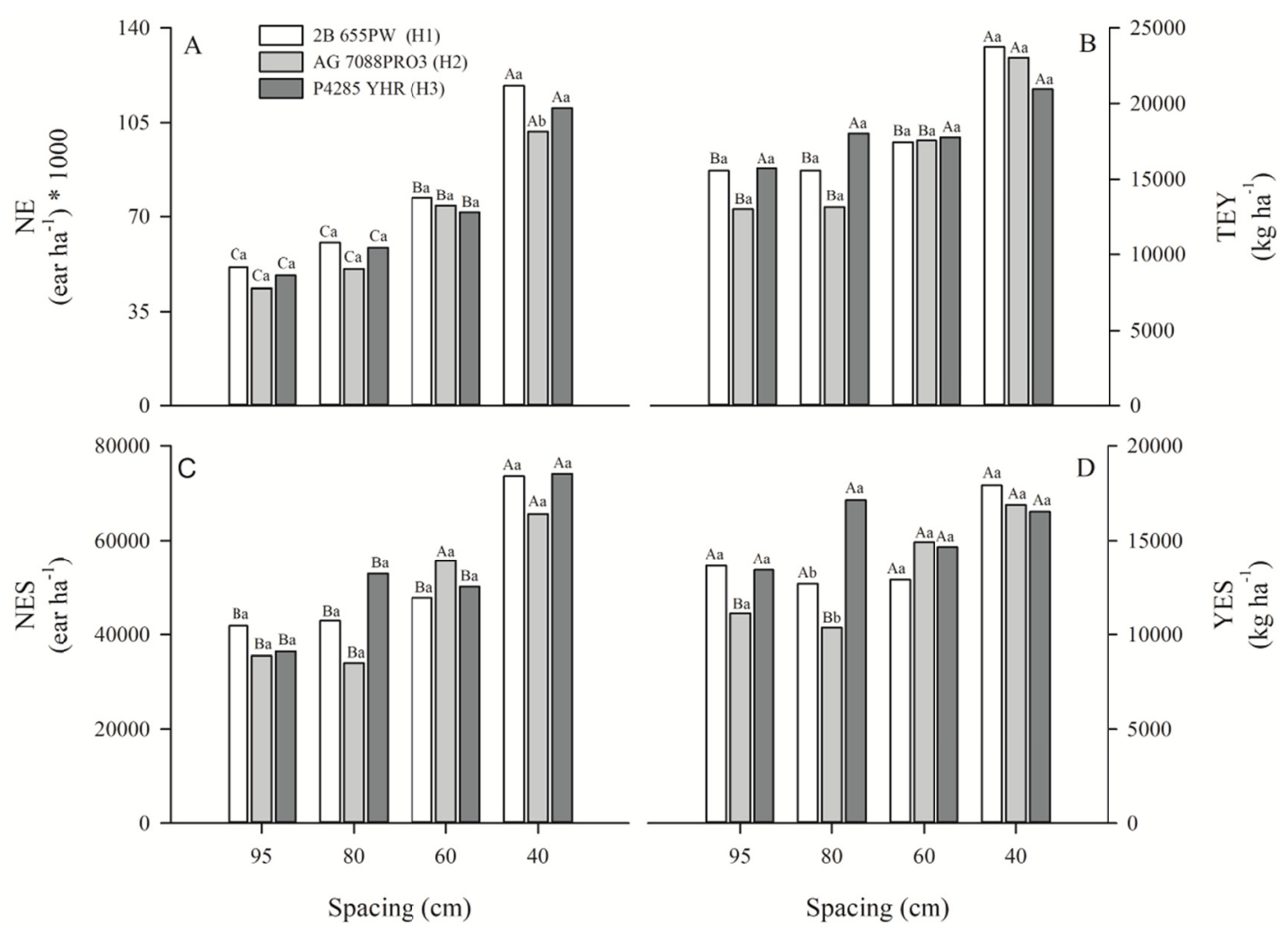

Figure 2. Total number of ear (A), total ear yield (B), number of ears with straw (C) and yield ears with straw (D) of maize hybrids submitted to different spacing

Note. Averages followed by the same upper and lower case letters do not show statistical difference $(p>0.05)$ between the spacings and hybrids, respectively, by the Scott-Knott test.

The number of ears harvested at $40 \mathrm{~cm}$ spacing ranged from $101,736.00$ to $118,586.00$ ears $\mathrm{ha}^{-1}, 100 \%$ higher than the amount obtained when hybrids were sown $95 \mathrm{~cm}$ apart (Figure 2A). In this case, the number of plants increases with the reduction of spacing in the crop, which consequently increases the number of ears harvested per area. Testa, Reyneri, and Blandino (2016) state that the average number of ears harvested per unit area increases significantly as the plant population density increase due to the reduction in row spacing.

However, the NE was below the target plant population in all spacings, since the final stand was lower than expected for spacing treatments. For Favarato et al. (2016), the number of ears harvested per hectare present values below the total plant population per hectare. Noteworthy, that the final stand is dependent on seed germination, establishment and development of crop in the field (Vian et al., 2016). Additionally, factors such as stress at critical germination stages, seed emergence, and late vegetative growth may influence some growth and yield variables, including the final stand (Thapa et al., 2018).

The larger number of ear in the $40 \mathrm{~cm}$ spacing provided higher total ear yield (Figure 2B) for the hybrid $\mathrm{H} 1$ $\left(23,737.03 \mathrm{~kg} \mathrm{ha}^{-1}\right)$ and $\mathrm{H} 2\left(23,029.51 \mathrm{~kg} \mathrm{ha}^{-1}\right)$, respectively. However, the same result was not observed for $\mathrm{H} 3$, as it presented statistically equal TEY between the different spacings studied. Thus, the hybrid $\mathrm{H} 3$ presents higher TEY than the other hybrids, and it can be cultivated in normal or reduced spacing without suffering decline in total green ear yield.

The number of ears with straw (NES) per hectare (Figure 2C) was obtained by removing the ears affected by pests and diseases. In the reduced spacing $(40 \mathrm{~cm})$, there was an increase of $43.25 \%, 45.82 \%$ and $50 \%$ for hybrids $\mathrm{H} 1, \mathrm{H} 2$ and $\mathrm{H} 3$, respectively, in relation to the $95 \mathrm{~cm}$ spacing between rows. For the yield of ears with 
straw (YES), the hybrid H3 was superior because it did not show significance in the YES due to the reduction of the spacing (Figure 2D), with $8009.92 \mathrm{~kg} \mathrm{ha}^{-1}$ for the cultivation in the spacing $40 \mathrm{~cm}$ between rows and $6275.83 \mathrm{~kg}$ $\mathrm{ha}^{-1}$ at $95 \mathrm{~cm}$. According to Silva, Schimitz, Silva, Carpanini, and Magalhães (2015) the productivity of ears with straw is an important characteristic for commercialization of green maize, since the ears can be sold with straw, which gives it a longer shelf life.

For the number of ears without straw (NEWS) per hectare (Figure 3A), a significant difference was found only between the spacings $(p<0.05)$. However, the yield of ears without straw (YEWS) was not influenced $(p>0.05)$ by the spacing (Figure 3B). For ear length and diameter (Figures 3C and 3D) were observed significant differences between hybrids and spacing.

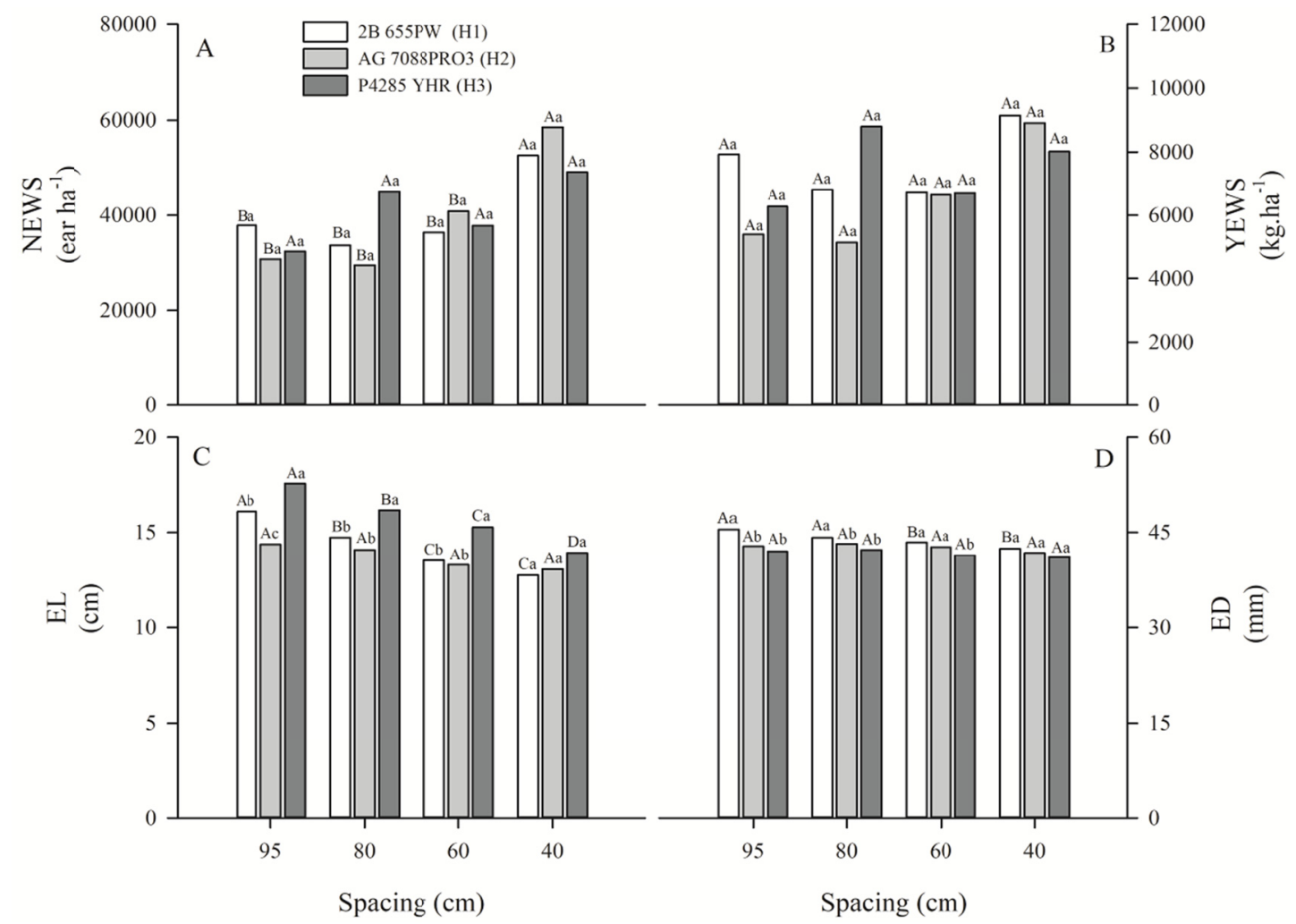

Figure 3. Number of ears without straw (A), yield of ears without straw (B), ear length (C) and ear diameter (D) of maize hybrids in their respective spacing

Note. Averages followed by the same upper and lower case letters do not show statistical difference $(\mathrm{p}>0.05)$ between the spacings and hybrids, respectively, by the Scott-Knott test.

Notably, the high number of ears without straw (NEWS) per hectare in the $40 \mathrm{~cm}$ spacing (Figure 3A) was due to the higher population density obtained with the smaller cultivated area spacing. Noteworthy that only $\mathrm{H} 3$ maintained NEWS statistically equal between the evaluated spacings, which suggests superiority to the other hybrids.

The yield of ear without straw (YEWS) per hectare (Figure 3B) was not influenced by the treatments, with an average ranging from $5,133.52$ to $9,140.54 \mathrm{~kg} \mathrm{ha}^{-1}$. These characteristics have great relevance in the production of green maize, because the ears without straw are the products required for consumption of the grains in the ear itself or for use in industry (Carvalho et al., 2016).

The length and diameter of green ears for commercialization are at least $15 \mathrm{~cm}$ and $30 \mathrm{~mm}$, respectively, for ears without straw (Silva et al., 2015). In this research, H3 presented superiority to the other hybrids in the $95 \mathrm{~cm}, 80$ $\mathrm{cm}$ and $60 \mathrm{~cm}$ spacing, with an ear length of $17.58 \mathrm{~cm}, 16.18 \mathrm{~cm}$ and $15.27 \mathrm{~cm}$, respectively. Regarding the ear diameter (Figure 3D), even presenting differences in the hybrid and spacing treatments, the average values ranged from 41.05 to $45.48 \mathrm{~mm}$ which is in the standard established for the market of green maize for in natura consumption. 
The path analysis under multicollinearity with the addition of the constant $\mathrm{k}=0.05$ was efficient to estimate the direct and indirect effects of the explanatory variables on the YEWS (Table 2). The coefficient of determination was $96.00 \%$ and the low residual effect $(0.20)$, shows that the components PH, EIH, SD, LA, EL and ED determined the total variation of YEWS in maize hybrids cultivated with reduced spacing for green ear production.

Table 2. Estimates of the direct and indirect effects of the primary variables plant height (PH), ear insertion height (EIH), stem diameter (SD), leaf area (LA), ear length (EL) and ear diameter (ED) on the main variable yield without straw (YEWS) of corn hybrids cultivated in reduced spaced environment

\begin{tabular}{|c|c|c|c|}
\hline Characters & Path coefficients & Characters & Path coefficients \\
\hline$P H$ & & $L A$ & \\
\hline Direct effect on YEWS & -0.10 & Direct effect on YEWS & 0.17 \\
\hline Indirect effect via EIH & -0.33 & Indirect effect via $\mathrm{PH}$ & -0.10 \\
\hline Indirect effect via SD & -0.41 & Indirect effect via EIH & -0.28 \\
\hline Indirect effect via LA & 0.17 & Indirect effect via SD & -0.33 \\
\hline Indirect effect via EL & 0.35 & Indirect effect via EL & 0.50 \\
\hline Indirect effect via ED & -0.17 & Indirect effect via ED & -0.01 \\
\hline Total & -0.35 & Total & -0.06 \\
\hline$E I H$ & & $E L$ & \\
\hline Direct effect on YEWS & -0.34 & Direct effect on YEWS & 0.65 \\
\hline Indirect effect via $\mathrm{PH}$ & -0.10 & Indirect effect via $\mathrm{PH}$ & -0.06 \\
\hline Indirect effect via SD & -0.45 & Indirect effect via EIH & -0.09 \\
\hline Indirect effect via LA & 0.14 & Indirect effect via SD & -0.06 \\
\hline Indirect effect via EL & 0.17 & Indirect effect via LA & 0.13 \\
\hline Indirect effect via ED & -0.02 & Indirect effect via ED & -0.01 \\
\hline Total & -0.61 & Total & 0.61 \\
\hline$S D$ & & $E D$ & \\
\hline Direct effect on YEWS & -0.45 & Direct effect on YEWS & 0.02 \\
\hline Indirect effect via $\mathrm{PH}$ & -0.10 & Indirect effect via $\mathrm{PH}$ & 0.10 \\
\hline Indirect effect via EIH & -0.34 & Indirect effect via EIH & 0.32 \\
\hline Indirect effect via LA & 0.13 & Indirect effect via SD & 0.39 \\
\hline Indirect effect via EL & 0.08 & Indirect effect via LA & -0.17 \\
\hline Indirect effect via ED & -0.02 & Indirect effect via EL & -0.40 \\
\hline Total & -0.71 & Total & 0.26 \\
\hline Coefficient of determination & & 0.96 & \\
\hline $\mathrm{k}$ value & & 0.05 & \\
\hline Residual variable effect & & 0.20 & \\
\hline
\end{tabular}

The highest total correlation coefficients obtained in the experiment between EL and YEWS ( $r=0.61)$, EIH and YEWS $(r=-0.61)$ and between SD and YEWS $(r=-0.71)$ resulted in the highest average direct effects of EL, EIH and SD on the yield of ears without straw, with coefficients of $0.65,-0.34$ and -0.45 , respectively. These results confirm the importance that EL, EIH and SD have in the cause and effect relationship with the dependent variable, and that the indirect selection of these variables can result in significant gains in YEWS.

These characters PH, LA and ED had a direct effect smaller than the residual variable and their associations may not be relevant for YEWS since components with positive or negative direct effects smaller than the residual variable indicate that the components are not cause and effect of the basic variable (Toebe \& Cargnelutti Filho, 2013).

With the path analysis Entringer et al. (2014), observed that the components green ear volume and grain volume may favor the gain in green ear production in a simultaneous selection process, since the direct effect of the explanatory variables were 0.2536 and 0.2637 , respectively, in the production of green ear. Thus, selection of EL, EIH and SD can help in choosing superior cultivars for green ear production. 
In the production of green ears of corn, in crops that cultivate in small spacing, the characteristics EL, EIH and SD directly and indirectly influenced the yield of green ears without straw. Results provide different options of variables that can be selected to maximize genetic gain in green ear production of maize hybrids in reduced spacing.

\section{Conclusions}

Hybrids can be grown in reduced row spacing up to $60 \mathrm{~cm}$ to increase green ear yield without changing plant growth characteristics.

The diameter and length of strawless ear of hybrids grown up to $60 \mathrm{~cm}$ between rows are satisfactory for commercialization and consumption in nature.

The characters ear length (EL), ear insertion height (EIH) and stem diameter (SD) have the largest direct and indirect contribution at yield ear without straw.

\section{Acknowledgements}

This work was supported by grants from the Coordination for the Improvement of Higher Education Personnel (CAPES), Federal University of Acre and Fazenda São João.

\section{References}

Almeida Júnior, J. J., Smiljanic, K. B. A., Matos, F. S. A., Miranda, B. C., Oliveira, D. M., \& Camargo, H. A. (2018). Características agronômicas e produtividade na cultura do milho plantado com diferentes populações na região de mineiros estado de goiás. Nucleus, 15(2), 475-483. https://doi.org/10.3738/1982.2278.2881

Carvalho, I. D., Ferreira, P. V., Silva Júnior, A. B., Teixeira, J. S., Oliveira, F. S., Carvalho, A. P., \& Santos, P. R. (2016). Análise produtiva de genótipos de milho-verde consorciados com feijão. Horticultura Brasileira, 34(4), 593-599. https://doi.org/10.1590/S0102-053620160422

Costa, F. R., Damaso, L. F., Mendes, R. C., Marques, D. D., \& Rodrigues, F. (2015). Desempenho de híbridos de milho para consumo in natura em diferentes doses de nitrogênio. Científica, 43(2), 109-116. https://doi.org/10.15361/1984-5529.2015v43n2p109-116

Cruz, C. D. (2016). Genes Software-Extended and integrated with the R, Matlab and Selegen. Acta Scientiarum, 38(4), 547-552. https://doi.org/10.4025/actasciagron.v38i4.32629

Cruz, C. D., \& Carneiro, P. C. S. (2006). Modelos biométricos aplicados ao melhoramento genético (2nd ed., p. 585). Viçosa, Imprensa Universitária.

Entringer, G. C., Santos, P. H. A. D., Vettorazzi, J. C. F., Cunha, K. S., \& Pereira, M. G. (2014). Correlação e análise de trilha para componentes de produção de milho superdoce. Revista Ceres, 61(3), 356-361. https://doi.org/10.1590/s0034-737x2014000300009

Favarato, L. F., Souza, J. L., \& Galvão, J. C. C. (2016). Crescimento e produtividade do milho-verde sobre diferentes coberturas de solo no sistema plantio direto orgânico. Bragantia, 75(4), 497-506. https://doi.org/ $10.1590 / 1678-4499.549$

INMET (Instituto Nacional de Meteorologia). (2017). Informações de estações meteorológicas 2016-2017. Retrieved September 10, 2019, from http://www.inmet.gov.br

Kuneski, H. F., Leolato, L. S., Sangoi, L., Coelho, A. E., Durli, M. M., \& Panison, F. (2017). Regulador de crescimento e características morfológicas do milho em diferentes densidades de plantas e épocas de semeadura. Revista Congrega Urcamp, 14, 2497-2512.

Luz, J. M., Camilo, J. S., Barbieri, V. H., Rangel, R. M., \& Oliveira, R. C. (2014). Produtividade de genótipos de milho doce e milho verde em função de intervalos de colheita. Horticultura Brasileira, 32, 163-167. https://doi.org/10.1590/S0102-05362014000200007

Montgomery, D. C., \& Peck, E. A. (1981). Introduction to linear regression analysis (p. 504). New York, John Wiley.

Nascimento, L. O., Ferreira, J. B., Martins, M. O., Nascimento, G. O., \& Lima, A. F. B. (2019). Effects of reduced spacing on maize productivity, $\mathrm{CO}_{2}$ assimilation and gas exchange. African Journal of Agricultural Research, 14(5), 226-231. https://doi.org/10.5897/AJAR2018.13794

Rezende, W. S., Brito, C. H. de, Brandão, A. M., Franco, C. J. F., Ferreira, M. V., \& Ferreira, A. S. (2015). Desenvolvimento e produtividade de grãos de milho submetido a níveis de desfolha. Pesquisa Agropecuaria Brasileira, 50(3), 203-209. https://doi.org/10.1590/S0100-204X2015000300003 
Ribeiro, M. C., Damaso, L. F., Costa, F. R., Pelá, A., \& Rodrigues, F. (2016). Híbridos de milho sob diferentes doses de fósforo visando o consumo in natura. Magistra, 28(2), 273-278.

Rocha, R. S., Nascimento, M. R., Chagas, J. T. B., Almeida, R. N., Santos, P. R., Cruz, D. P., ... Daher, R. F. (2019). Association among Agro-morphological Traits by Correlations and Path in Selection of Maize Genotypes. Journal of Experimental Agriculture International, 34(2), 1-12. https://doi.org/10.9734/jeai/ 2019/v34i230170

Rodrigues, F., Melo, P. G. S., Resende, C. L. P., Mrojinski, F., Mendes, R. C., \& Silva, M. A. (2018). Aptidão de híbridos de milho para o consumo in natura. Revista de Ciências Agrárias, 41(2), 211-220. https://doi.org/10.19084/RCA17216.

Santos, N. C. B., Carmo, S. A., Mateus, G. P., Komuro, L. K., Pereira, L. B., \& Souza, L. C. D. (2015). Características agronômicas e de desempenho produtivo de cultivares de milho-verde em sistema orgânico e convencional. Semina, 36(3), 1807-1822. https://doi.org/10.5433/1679-0359.2015v36n3Supl1p1807

Silva, F. de A. S., \& Azevedo, C. A. V. de. (2016). The Assistat Software Version 7.7 and its use in the analysis of experimental data. African Journal of Agricultural Research, 11(39), 3733-3740. https://doi.org/10.5897/ AJAR2016.11522

Silva, G. C., Schimitz, R., Silva, L. C., Carpanini, G. G., \& Magalhães, R. C. (2015). Desempenho de cultivares para produção de milho verde na agricultura familiar do sul de Roraima. Revista Brasileira de Milho e Sorgo, 14(2), 273-282. https://doi.org/10.18512/1980-6477/rbms.v14n2p273-282

Silveira, D. C, Bonetti, L. P., Tragnago, J. L., Neto, N., \& Monteiro, V. (2015). Caracterização agromorfológica de variedades de milho crioulo (Zea mays L.) na região noroeste do Rio Grande do Sul. Revista Ciência e Tecnologia, 1(1), 1-11.

Testa, G., Reyneri, A., \& Blandino, M. (2016). Maize grain yield enhacement trough high plant density cultivation with different inter-row spacings. European Journal of Agronomy, 72, 28-37. https://doi.org/ 10.1016/j.eja.2015.09.006

Thapa, S., Stewart, B. A., Xue, Q., Rhoades, M. B., Angira, B., \& Reznik, J. (2018). Canopy temperature, yield, and harvest index of corn as affected by planting geometry in a semi-arid environment. Field Crops Research, 227, 110-118. https://doi.org/10.1016/j.fcr.2018.08.009

Toebe, M., \& Cargnelutti Filho, A. (2013). Multicollinearity in path analysis of maize (Zea mays L.). Journal of Cereal Science, 57(3), 453-462. https://doi.org/10.1016/j.jcs.2013.01.014

Vian, A. L., Santi, A. L., Amado, T. J. C., Cherubin, M. R., Simon, D. H., Damian, J. M., \& Bredemeier, C. (2016). Variabilidade espacial da produtividade de milho irrigado e sua correlação com variáveis explicativas de planta. Ciência Rural, 46(3), 464-471. https://doi.org/10.1590/0103-8478cr20150539

Williams, M. M. (2014). Few crop traits accurately predict variables important to productivity of processing sweet corn. Field Crops Research, 157, 20-26. https://doi.org/10.1016/j.fcr.2013.12.003

Zuffo, A. M., Ribeiro, A. B. M., Bruzi, A. T., Zambiazzi, E. V., \& Fonseca, W. L. (2018). Correlações e análise de trilha em cultivares de soja cultivadas em diferentes densidades de plantas. Revista de Ciências Agronômicas, 27(1), 78-90.

\section{Copyrights}

Copyright for this article is retained by the author(s), with first publication rights granted to the journal.

This is an open-access article distributed under the terms and conditions of the Creative Commons Attribution license (http://creativecommons.org/licenses/by/4.0/). 